\title{
サーモグラフィー法による外壁仕上げ材の剥離検知の 適用限界に関する実験的研究 \\ EXPERIMENTAL STUDY ON LIMITATION OF THERMOGRAPHIC SURVEY APPLIED TO DETECTION OF DELAMINATION OF FINISHING MATERIALS ON EXTERNAL WALL
}

\author{
込山貴仁*, 中野米蔵**, 谷川恭雄*** \\ Tatsuhito KOMIYAMA, Yonezou NAKANO and Yasuo TANIGAWA
}

\begin{abstract}
As a means of the detection of delaminated mortar or tile, thermographic survey using thermal imager has advantages of easiness, rate of data sampling, and safety. However, since this method is based on the lack of conductivity of the delaminated area in comparison with that of the sound anea, the limitations of this method depend largely upon natural weathering.

In this experiment, in stead of exposing specimens to the sunlight, temperature differences equivalent to the heat which should be given to the specimens by solar radiation were made. As a result, the availability and limitations of this method were clarified.
\end{abstract}

Keywords : delamination, finish, mortar, thermography 剥離，仕上げ，モルタル，サーモグラフィー

\section{1. はじめに}

近年，タイル・モルタル等の外壁仕上げ材の落下によ る災害が頻発し，一種の社会問題となった。その結果, 外壁仕上げ材の剥離部を検知するためのさまざまな非破 罗検查手法が開発され，その一部は既に実用に供されて いる。その中で, 赤外線映像装置を用いて外壁の表面温 度分布を測定するサーモグラフィー法は，足場の設置を 必要とせず，危険な高所作業も伴わず，大面積の壁面を 短時間に測定することが可能であることから注目を集め, 現在も盛んに使用されている。しかしながら，この手法 は，その簡便さゆえに十分な基砧研究を経ずして実用化 されたために，知識や経験の不十分な測定者による誤診 の事例が少なからず生じている。今日では徐々にサーモ グラフィー法に関する基礎研究が進み, 本手法の問題点, それに対する対策，適用限界などが次第に明らかにされ つつあるが，まだ適用方法の標準化には至っていない。 サーモグラフィー法に関する基礎研究としては，筆者
らによる実構造物大の試験体を用いた実験的研究 ${ }^{1)}$, 内 山らによる最適検出波長帯に関する研究 ${ }^{2)}$ ながありり， 適用限界の確認に関しても新井ら, 筆者らにより, 有限 要素法を用いた非定常熱伝導解析による検討がなされて

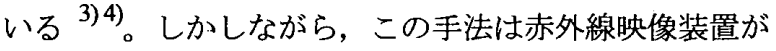
表示寸る外壁の表面温度分布から，測定者が自身の判断 で, 健全部と剥離部を判定するものであるため, 解析上 の適用限界が，必ずしも肉眼での剥離の認識が可能な限 界と一致するとは限らない。このような立場から, 実験 的研究は不可欠であるにもかかわらず，まだ適用限界に

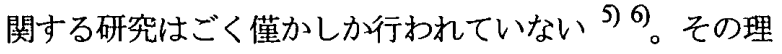
由は, 本手法の適用限界が日射量や気温など, 再現性の ない気象条件を因子として持つことにある。本来，この 手法はその原理上, 気象条件, 外壁の周囲の環境等, さ まざまな影響因子により，その信頼性や適用範囲が大き く左右される。したがって, 自然の日射や気温変化を熱 源とする実験的研究では, あくまで実験当日の気象条件
本論文の一部は，引用文献5)および6)に発表した。

* 名古屋大学工学部建築学科 大学院生

**コンステック 専務取縍役

*** 名古屋大学工学部建築学科 教授. 工博
Graduate Student, School of Architecture, Faculty of Engineering, Nagoya University

Managing Director, Constec Co.

Prof., School of Architecture, Faculty of Engineering, Nagoya University, Dr. Eng. 
下での適用限界を確認したことにしかならず，厳密な意 味での適用限界を明らかにしたことにはならない。そこ で，本研究では，模擬的剥離を有する試験体に，東西南 北の各方位の壁面が理想的な環境下で受熱する日射量お よび気温変化に相当する熱量を人工的に与え, サーモグ ラフィー法により剥離を検知することが可能なモルタル 厚さの限界について実験的に検討した。以下に，その結 果を報告する。

\section{2. サーモグラフィー法に閏わる外界気候}

2. 1 外壁の熱収支

図 1 は，外界気候の変化に伴う外壁の熱収支を示した モデルである。図のように外壁の表面温度は，日射およ び空気中の分子からの対流熱伝達, 放射熱伝達により変 化する。したがって, 空調等を考えない場合, 外壁の表 面温度は日射および気温に支配されると考えてよい。

\section{2 サーモグラフィー法の原理}

サーモグラフィー法による剥離検知の原理図を図 2 に 示す。同図からわかるように, サーモグラフィー法は, 外壁の仕上げ材と躯体との間に生じた剥離部の空隙が断 熱層となり，日射や気温変化に起因して生じる外壁の表 面温度の日変動の中で, 剥離部と健全部との間に表面温 度差が生じる時間帯があることを利用して, 外壁の表面

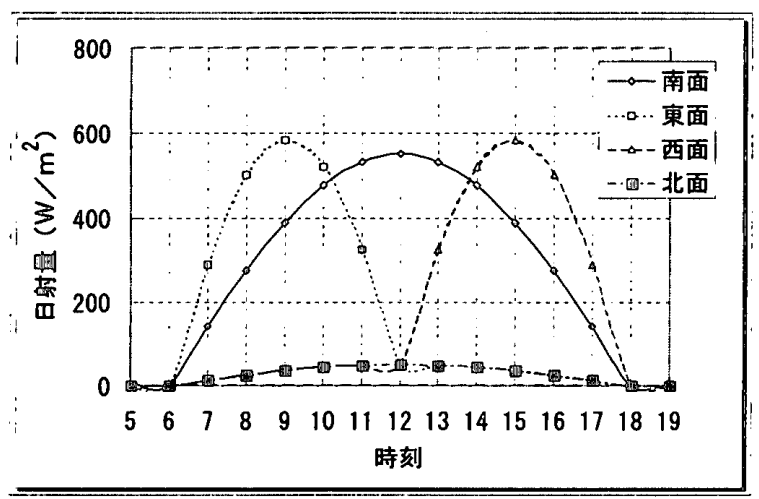

図 3 春分の日射量

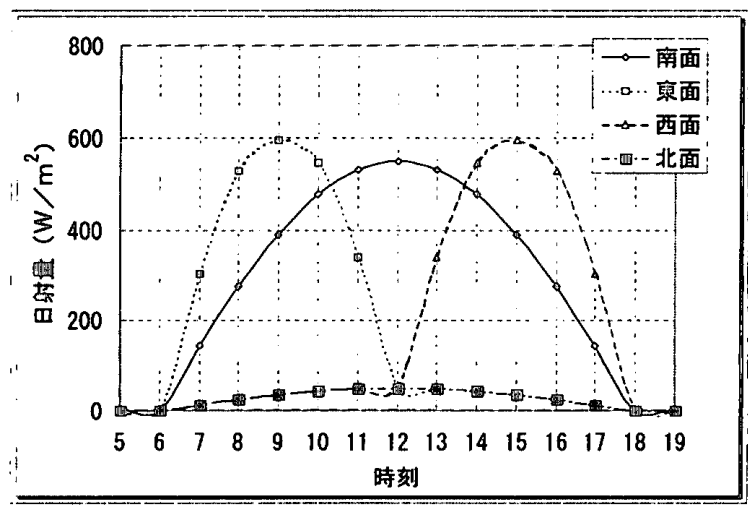

図 5 秋分の日射量

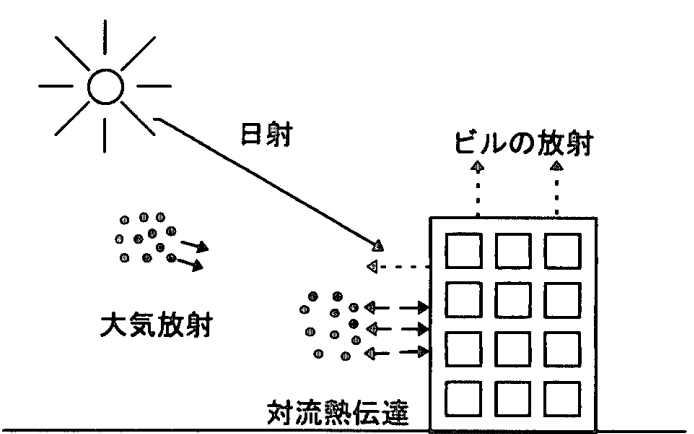

図 1 外壁の熱収支モデル

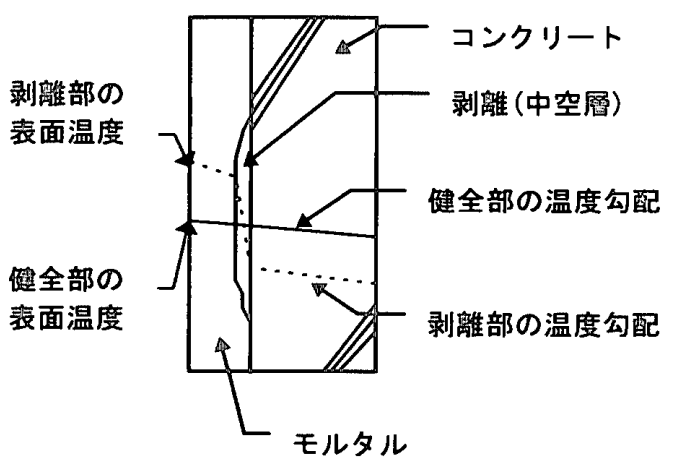

図 2 剥離検知の原理図

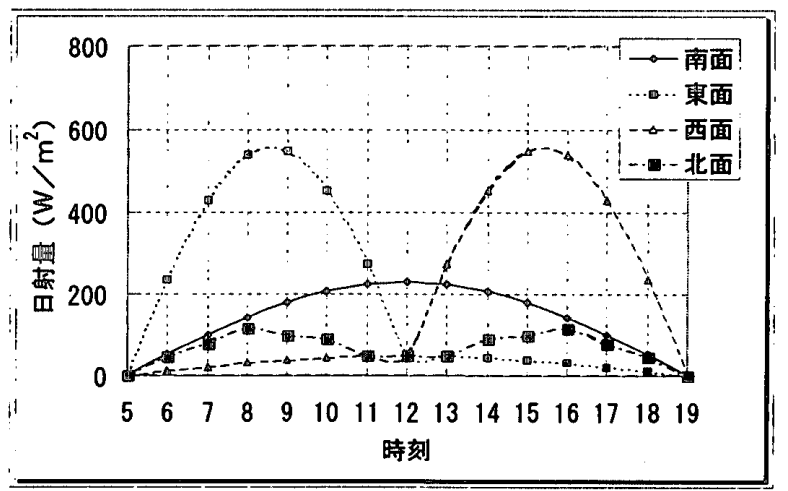

図 4 夏至の日射量

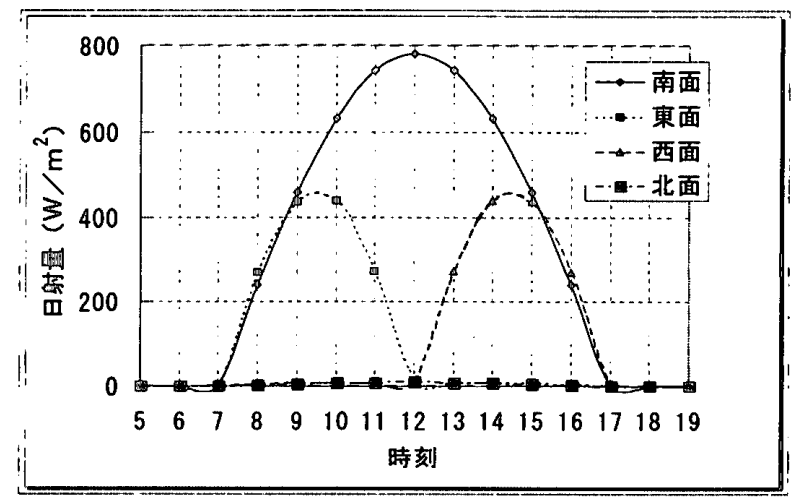

図 6 冬至の日射量 
表1 実験に用いた想定気象条件

\begin{tabular}{|c|c|c|c|c|}
\hline 方位 & 東面 & 西面 & 南面 & 北面 \\
\hline 季節 & 春分 & 春分 & 冬至 & 夏至 \\
\hline 天候 & 快晴 & 快晴 & 快晴 & 快晴 \\
\hline 最低気温 & $5^{\circ} \mathrm{C}(6$ 時 $)$ & $5^{\circ} \mathrm{C}(6$ 時 $)$ & $5^{\circ} \mathrm{C}(6$ 時 $)$ & $20^{\circ} \mathrm{C}(5$ 時) \\
\hline 最高気温 & $15^{\circ} \mathrm{C}(14$ 時 $)$ & $15^{\circ} \mathrm{C}(14$ 時 $)$ & $11^{\circ} \mathrm{C}(14$ 時) & $28^{\circ} \mathrm{C}(14$ 時 $)$ \\
\hline 室内側気温 & $10^{\circ} \mathrm{C}$ (一定) & $10^{\circ} \mathrm{C}$ (一定) & $8^{\circ} \mathrm{C}$ (一定) & $24^{\circ} \mathrm{C}$ (一定) \\
\hline 相対湿度 & $50 \%$ (一定) & $50 \%$ (一定) & 40\%(一定) & $70 \%$ (一定) \\
\hline 日射量 & 図 7 に示す & 図 7に示す & 図 7に示す & 図7に示す \\
\hline
\end{tabular}

温度分布から剥離を検知する手法である。したがって， 剥離部と健全部との間に検知可能な表面温度差が生じる ためには，十分な日射量と気温変化が必要となる。気温 の日較差は，その日の天候によりほぼ決まり，季節に よって若干の差異はあるが，快晴日の気温の日較差はお おむね $10^{\circ} \mathrm{C}$ 前後と考えてよい。一方，外壁に表面温度の 日変動を生じさせるもう一つの因子である日射量は，季 節，外壁の方位，天候により大きく変化し，また，大気 透過率の違いから地方によっても差異が生じる。図 3〜6 は，春分，夏至，秋分および冬至の東京における快晴日 の日射量の日変動の一例である 。同図より，同一地方 の同一方位の外壁に与えられる日射量は季節により大き く変化し, 南面については冬至, 東西面については春分 および秋分，北面については夏至に日射量が最大となる ことがわかる。

そこで，本研究では東西南北，それぞれの方位に面し た外壁について，日射量および気温の日較差が最大とな る季節，天候として表 1 に示す気象条件を仮定し，それ ぞれの外壁に図 7 に示すとおりの日射量が与えられるも のとして実験を行った。

\section{3. 実験概要}

3. 1 相当外気温度の概念

2.2で示した日射量および気温変化に相当する熱量 を人工的に与えるためには，遠赤外線ヒ一タなど による人工加熱が考えられるが，これらのヒータ には指向性があり，日射のように試験体全体を均 一に加熱することはできない。そこで，本研究で は，以下に示す相当外気温度の概念に基づいて， 外壁が受熱する熱量をすべて空気温度に換算し， 図 8 に示すように，屋外側および室内側の空気温

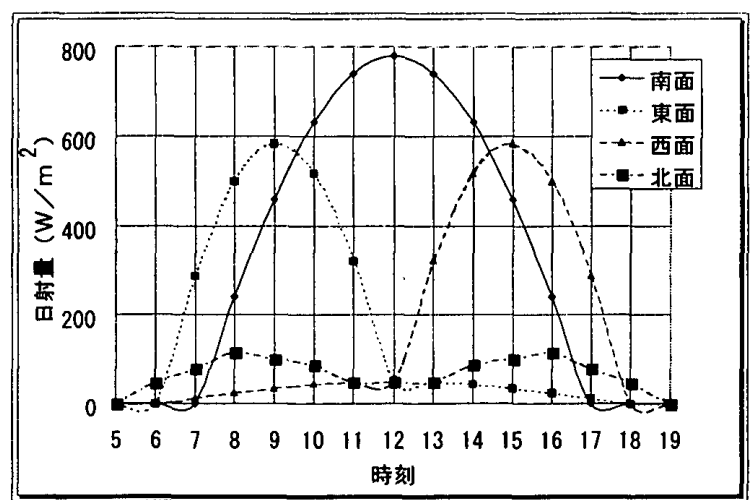

図 7 実験に用いた想定日射量

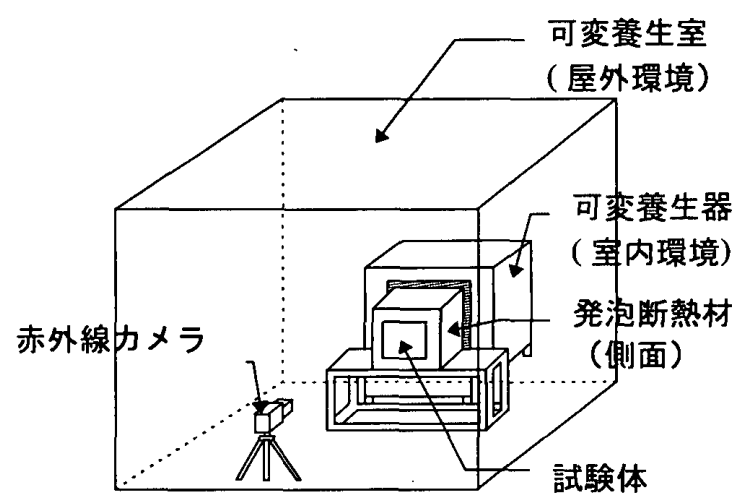

図 8 実験状況

表 2 相当外気温度の算出に用いた材料定数

\begin{tabular}{|c|c|c|c|c|}
\hline & $\begin{array}{c}\text { 総合熱伝達抵抗 } \\
\left(\mathrm{m}^{2} \cdot \mathrm{K} / \mathrm{W}\right)\end{array}$ & $\begin{array}{c}\text { 日射吸収率 } \\
(\%)\end{array}$ & $\begin{array}{c}\text { 放射率 } \\
(\%)\end{array}$ & $\begin{array}{c}\text { 夜間放射量 } \\
\left(\mathrm{W} / \mathrm{m}^{2}\right)\end{array}$ \\
\hline 無風時 & 0.108 & 75 & 90 & 0 \\
\hline 風速 $2 \mathrm{~m}$ 時 & 0.051 & 75 & 90 & 0 \\
\hline
\end{tabular}

$\theta_{\text {solair }}=\theta_{a}+R_{s o}\left(\varepsilon_{\text {sun }} \cdot J_{\text {sun }}+\varepsilon \cdot J_{\text {nit }}\right)$ いて制御することによって実験を行った。また，試験体 の側面は，側面からの熱の進入を防ぐために，厚さ 300 $\mathrm{mm}$ の発泡材を用いて断熱した。相当外気温度とは，日 射等により外壁に入射する熱量を，空気温度に換算して 評価寸る概念であり，式(1)により与えられる ${ }^{8)}$

$$
\begin{array}{ll}
\text { ここに, } & \\
\theta_{\text {solair }} & : \text { 相当外気温度 }\left({ }^{\circ} \mathrm{C}\right) \\
\theta_{a} & \left.: \text { 染気温度 }{ }^{\mathrm{C}} \mathrm{C}\right) \\
R_{\text {so }} & : \text { 外壁表面の総合熱伝達抵抗 }\left(\mathrm{m}^{2} \cdot \mathrm{K} / \mathrm{W}\right)
\end{array}
$$




$\begin{array}{ll}\varepsilon_{\text {ston }} & : \text { 外壁表面の日射吸収率 }(\%) \\ J_{s r n} & : \text { 日射量 }\left(\mathrm{W} / \mathrm{m}^{2}\right) \\ \varepsilon & : \text { 外壁表面の放射率 }(\%) \\ J_{n i t} & : \text { 夜間放射量 }\left(\mathrm{W} / \mathrm{m}^{2}\right)\end{array}$

式(1)に基づいて, 表 1 に示した気温変化および図 7 に 示した日射量変化を相当外気温度変化に換算した結果を 図 9 に示す。しかしながら，実際にはこのような高温下 での実験は不可能であるため, 実験は試験体を風速 $2 \mathrm{~m}$ ／ $\mathrm{s}$ 程度の熱風により強制加熱し，受熱量を向上させる ことにより，図 10 に示寸気温条件下で行った。なお, 相当外気温度への換算に用いた材料定数は表 2 に示すと おりであり，気温は式(2)に基づく余弦変動をするものと した。

$C=\frac{C \max +C \min }{2}-\frac{C \max -C \min }{2} \cdot \cos \left(\frac{T-T \min }{T \max -T \min } \cdot \pi\right)$ 式(2)

$\Xi こ に$

C : 気温 $\left({ }^{\circ} \mathrm{C}\right)$

C max : 最高気温 $\left.{ }^{\circ} \mathrm{C}\right)$

Cmin : 最低気温 $\left.{ }^{\circ} \mathrm{C}\right)$

$T \quad$ : 時刻

Tmax : 最高気温時刻

$T \min$ : 最低気温時刻

\section{2 実験方法}

実験に使用した試験体の形状・寸法を図11に示す。ま た，試験体の種類とモルタル厚さおよび剥離部の中空層 の厚さを表3に示す。

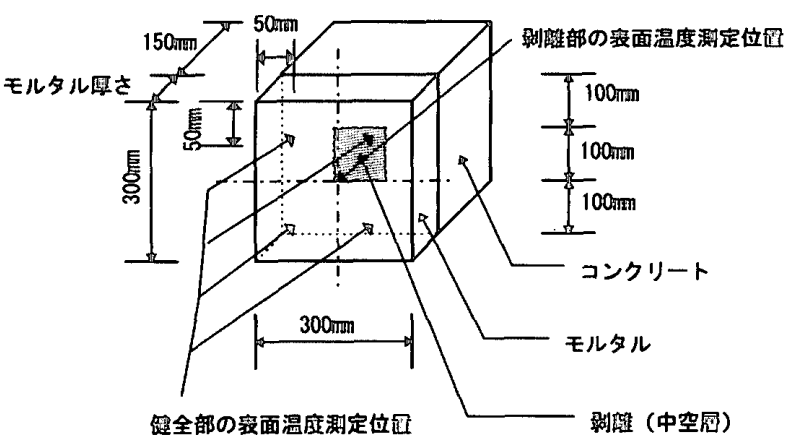

図11試験体の形状・寸法

\section{3 赤外線映像装置の仕様と表面温度の測定方法}

実験に使用した赤外線映像装置の仕様を表4に示す。 赤外線映像装置の感度は市販されている多くの赤外線映 像装置の最小検知温度差である $0.1^{\circ} \mathrm{C}$ に設定し，10分毎に 試験体の屋外側に相当する表面の熱画像を撮影した。な お，以下の記述において，剥離部の表面温度とは，図11

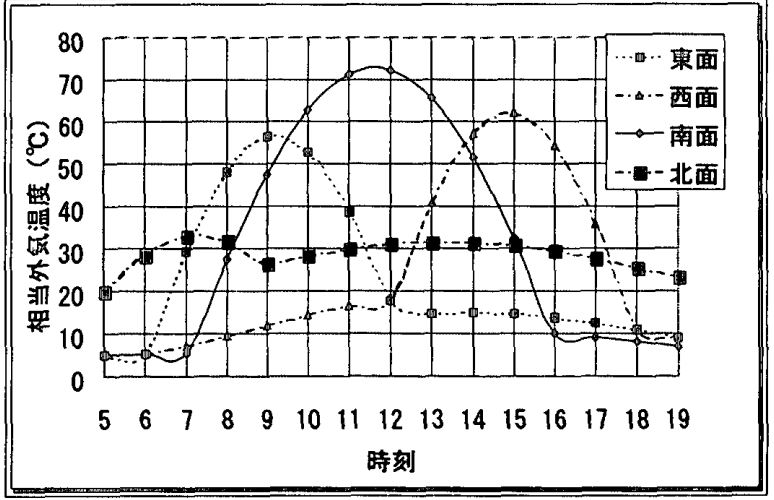

図9 相当外気温度換算値（無風時）

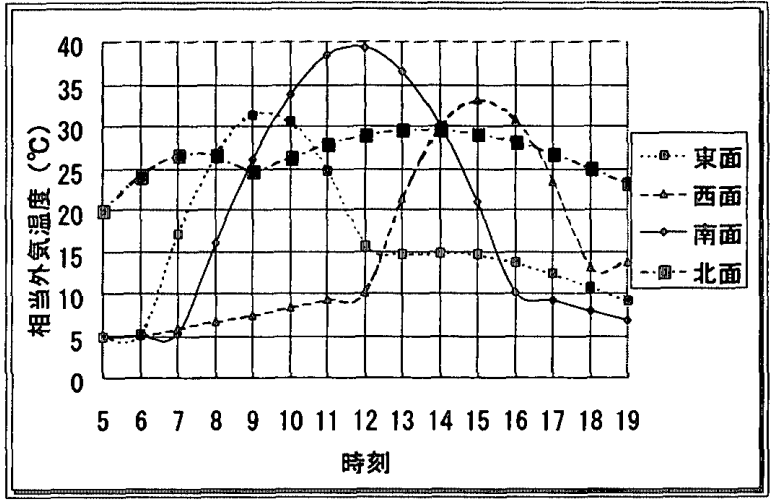

図10 相当外気温度換算值（強制加熱時）

表 3 試験体の種類と形状

\begin{tabular}{|c|c|c|}
\hline 試験体記号 & $\begin{array}{c}\text { モルタル厚さ } \\
(\mathrm{mm})\end{array}$ & $\begin{array}{c}\text { 中空層の厚さ } \\
(\mathrm{mm})\end{array}$ \\
\hline D 3 0W 1 & 30 & 1 \\
\hline D 7 0 W 1 & 70 & 1 \\
\hline D 7 0 W 0.5 & 70 & 0.5 \\
\hline D 1 0 0W 1 & 100 & 1 \\
\hline
\end{tabular}

表4 赤外線映像装置の仕様

\begin{tabular}{|c|c|}
\hline 測定温度範囲 & $-50 \sim 2000^{\circ} \mathrm{C}$ \\
\hline $\begin{array}{c}\text { 最小検知温度差 } \\
\left(30^{\circ} \mathrm{C} \text { 黒体測定時 }\right)\end{array}$ & $\begin{array}{c}0.1^{\circ} \mathrm{C} \\
\left(16 \text { 回積分時 } 0.025^{\circ} \mathrm{C}\right)\end{array}$ \\
\hline 検出波長帯 & $8 \sim 13 \mu \mathrm{m}$ \\
\hline 測定視野 & 水平 $30^{\circ}$, 垂直 $28.5^{\circ}$ \\
\hline 検出素子 & $\mathrm{Hg}-\mathrm{C} \mathrm{d}-\mathrm{T} \mathrm{e}$ \\
\hline 水平解像度 & 344 本以上 \\
\hline 瞬時視野 & $1.5 \mathrm{~m} \mathrm{r} \mathrm{a} \mathrm{d}$ \\
\hline 走查線数 & 207 本 \\
\hline フレ一ムタイム & 1秒 \\
\hline 冷却媒体 & $(16$ 回積分時 17 秒 $)$ \\
\hline
\end{tabular}


に示すように，赤外線映像装置によ り測定した剥離の中心部におけるモ ルタルの表面温度測定値であり，健 全部の表面温度とは，試験体の四隅 から50mm離れた 4 箇所におけるモ ルタルの表面温度測定值の平均値で ある。表面温度の測定に関しては赤 外線映像装置の積分機能を用い，16 回積分によるS/N改善を行うことに よって， $0.025^{\circ} \mathrm{C}$ 温度差まで読み 取った。

\section{4. 実験結果}

4. 1 表面温度変化

実験開始からの経過時間と表面温 度変化の関係を図12(健全部) ‘よ び図13(剥離部) に示す。表面温度 変化は東面が最も急激であり，南面 は緩やかな変化を示している。西面 は実験開始から270分までは緩やか な温度変化を示すが，その後，表面 温度は急激に上昇する。北面の表面 温度は実験開始後150分前後までは 日射量の上昇に伴って上昇するが， その後，日射量の減少に伴って，下 降傾向を示し，実験開始後270分前 後から気温の上昇に伴って再び上昇 している。実験開始から表面温度が 最高となるまでの表面温度の変化量 は南面で約 $22^{\circ} \mathrm{C}$, 東面では約 $16^{\circ} \mathrm{C}$,

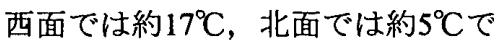
あり，モルタル厚さや剥離部の中空 層の厚さの違いによる影響は顕著に は現れていない。図14および図15に は，それぞれ健全部および剥離部の

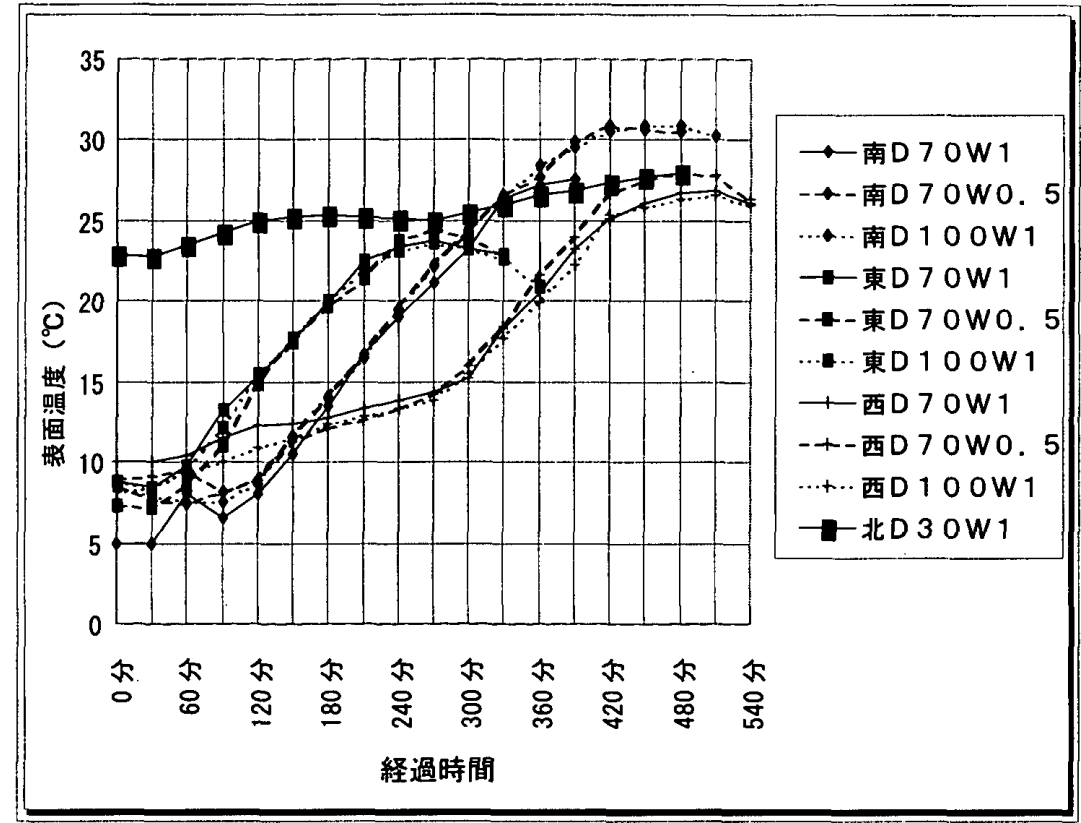

図12 健全部の表面温度変化

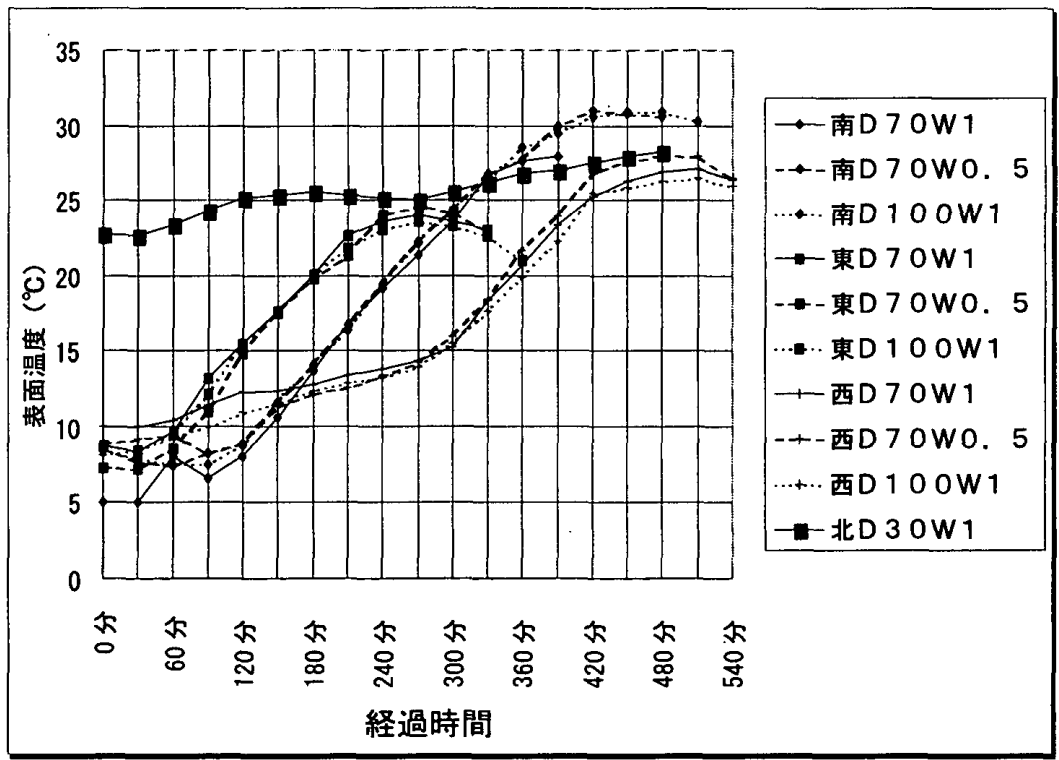

図13 剥離部の表面温度変化

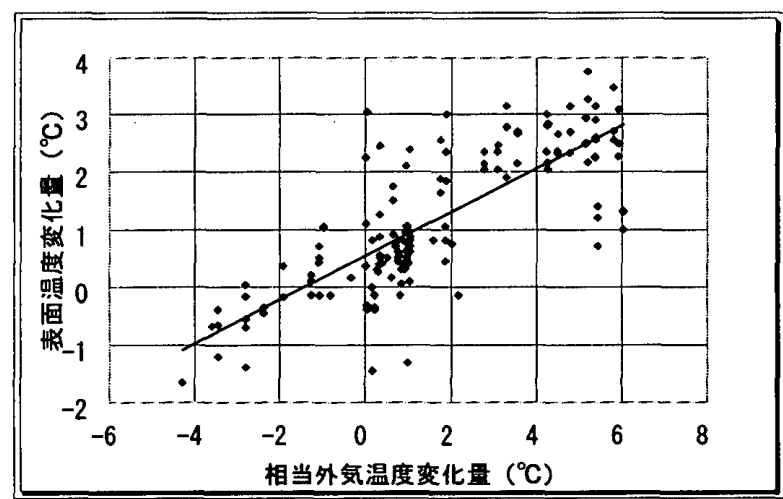

図14 相当外気温度変化量と表面温度変化量の関係 (健全部)

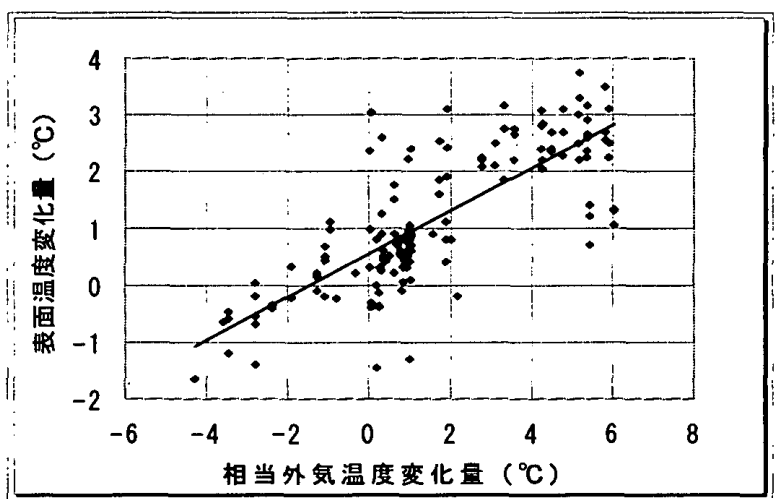

図15 相当外気温度変化量と表面温度変化量の関係 (剥離部) 
30分おきの相当外気温度変化量と表面温度変化量の関係 を示す。また，相当外気温度の変化量と表面温度の変化 量の関係についての回帰式を式(3)および式(4)に示す。

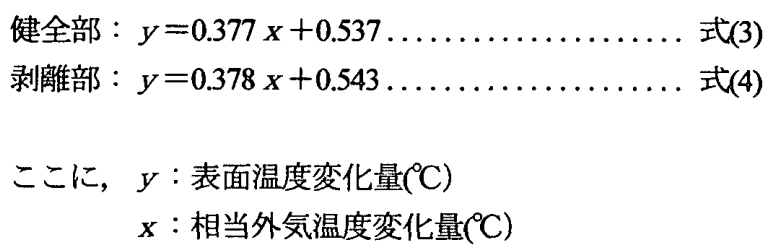

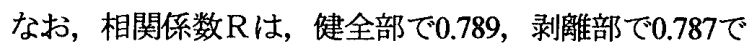
あった。これは，外壁の表面温度の変化量は相当外気温 度の変化量に関寸る 1 次の回帰式で表され，サーモグラ フィー法の適用に必要な外力エネルギー量の定量的指標 として, 相当外気温度の変化量を用いることができるこ とを示している。

\section{2 表面温度差}

図16〜図19にそれぞれ南面, 東面, 西面, 北面の時刻 と表面温度差(剥離部一健全部)の関係を示す。南面の試 験体D $70 W 1$ では, 8時前後から健全部と剥離部の間 に表面温度差が生じはじめるが，熱画像上で，肉眼でも 表面温度差の発生を認識できるのは9時前後からであり， 表面温度差が最大となる11時前後の熱画像では, 明瞭に 剥離が確認できる。また，10時前後から試験体D $70 \mathrm{~W}$ 0.5 に表面温度差が現れているが, 熱画像上では, 健全 部と剥離部の境界部に肉眼で確認できるほど鮮明な輪郭 は現れていない。東面の試験体D 70 W 1 については, 7時 30 分前後から健全部之剥離部の間に表面温度差が生 じはじめ, 8時30分頃には肉眼でも剥離と認識できるよ うになる。また，10時00分前後には試験体D $70 W 0.5$ に表面温度差が現れているが，南面同様に熱画像上での 認識は難しい。西面については，13時前後から試験体D $70 \mathrm{~W} 1$ に健全部と剥離部の間に表面温度差が生じはじ め, 14時頃には, 熱画像上でも肉眼で剥離を確認できる ようになり，16時前後には試験体D 70 W 0.5 に表面温 度差が現れる。しかし,この表面温度差は, 熱画像上で 肉眼により剥離の存在を認識できるものではない。北面 の試験体D $30 \mathrm{~W} 1$ では， $0.2^{\circ} \mathrm{C}$ 程度の微小な表面温度差 しか現九ないが, 剥離部の輪郭が比較的明膫で, 熱画像 上でも肉眼で剥離の存在を諗識できる。また，いずれの 方位に関しても試験体D $100 \mathrm{~W} 1$ の剥離は検知できな かった。また, 剥離が検知できた試験体に関しても, 肉 眼での剥離の認識が可能となる時刻は明瞭ではなく, 剥 離の中心部に生じた高温部の輪郭が次第に明瞭になり， 剥離と確認できるようになるという傾向があった。図20 ～図29に実験で得られた各試験体の熱画像の代表例を示 す。

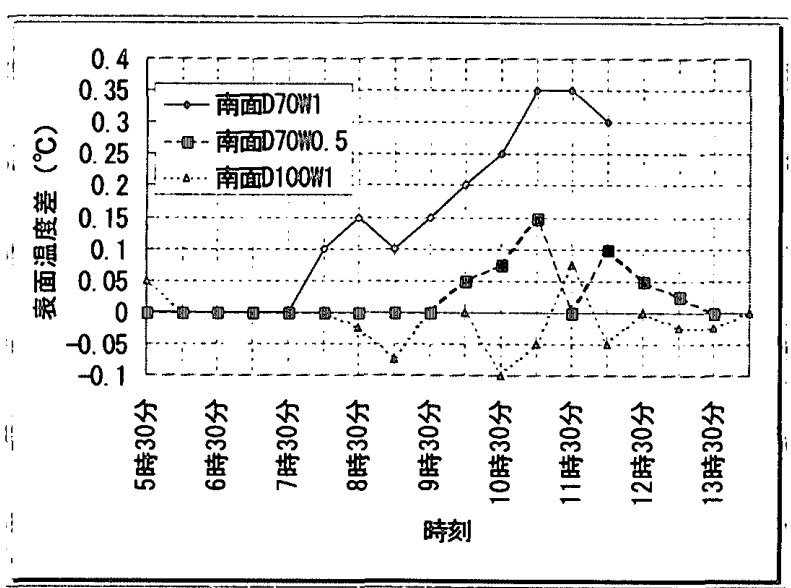

図16 表面温度差（剥離部一健全部）：南面

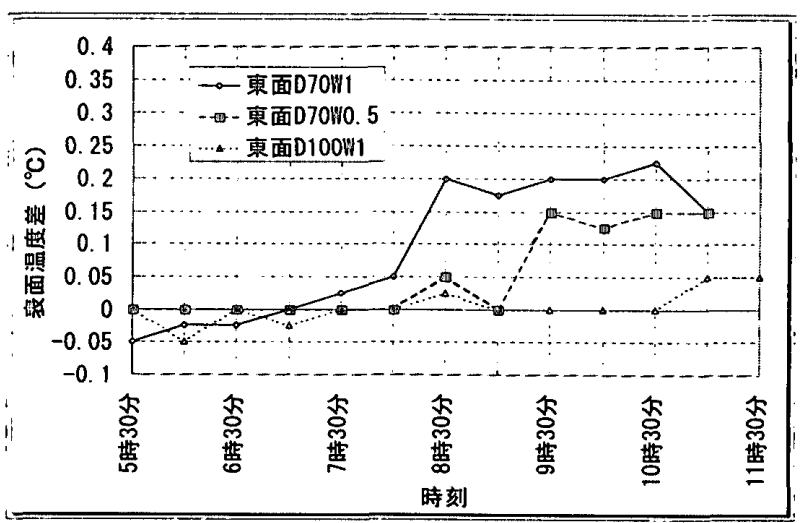

図17 表面温度差（剥離部一健全部）：東面

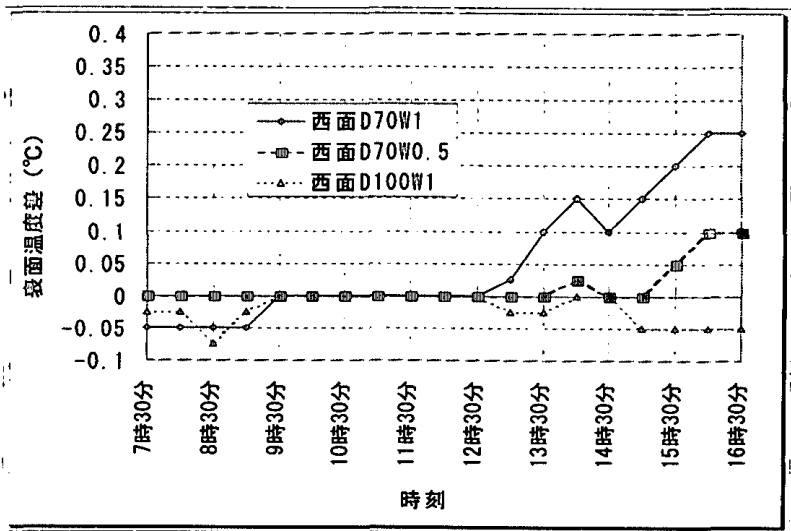

図18 表面温度差（剥離部一健全部）：西面

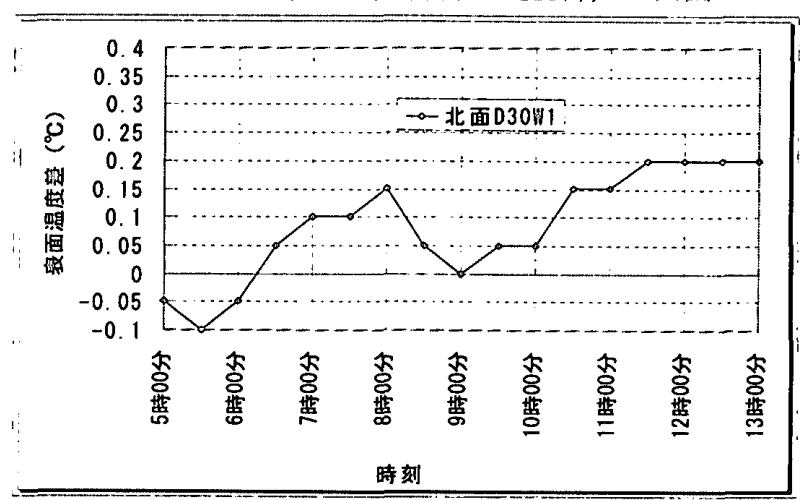

図19 表面温度差（剥離部一健全部）：北面 


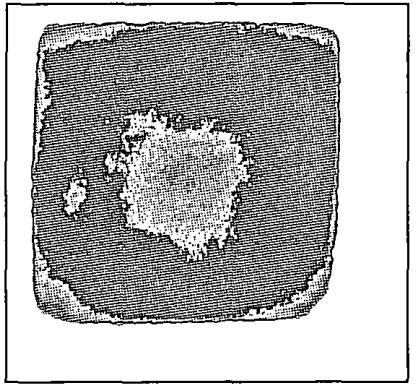

図 20 D 70 W 1 (南面) 11 時 00 分

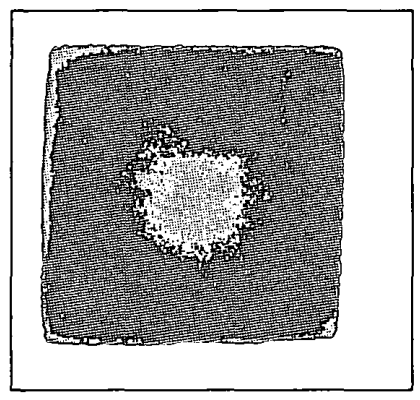

図 23D 70 W 1 (東面) 10 時 00 分

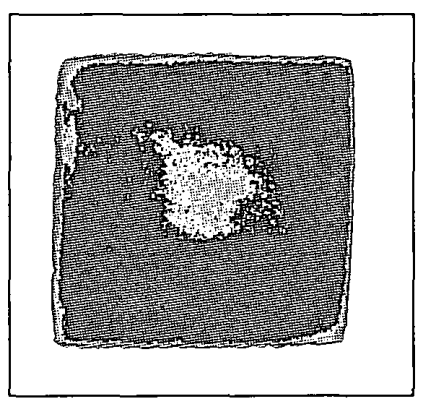

図 26 D 70 O 1 (西面) 15 時 30 分

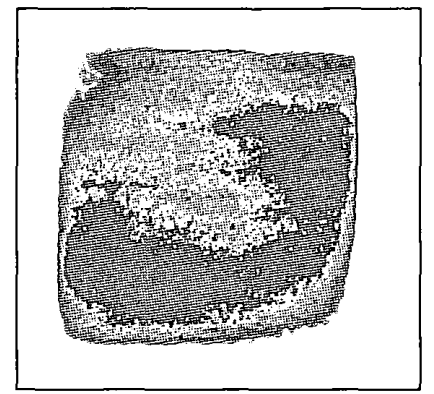

図 21 D 70 W 0.5 (南面) 11 時 00 分

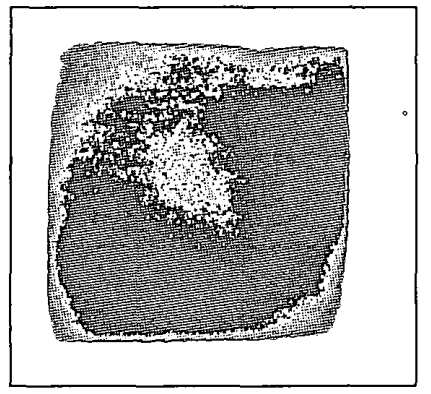

図 24 D 70 W0.5 (東面) 10 時 00 分

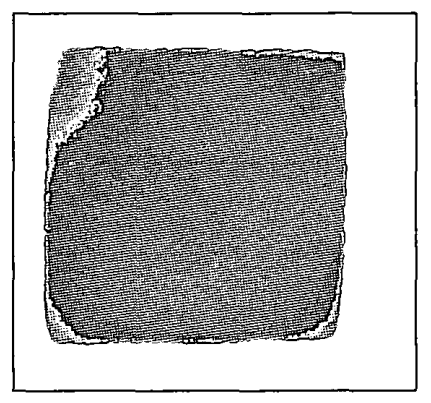

図27 D 70 W0.5 (西面) 15 時 30 分

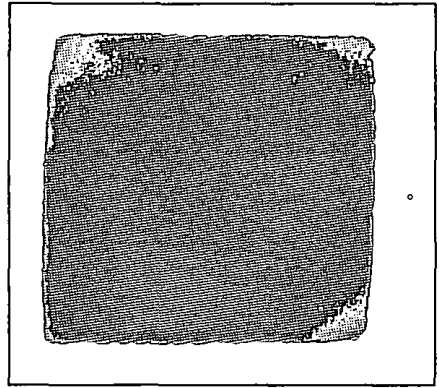

図 22 D $1000 \mathrm{~W} 1$ (南面) 11 時 00 分

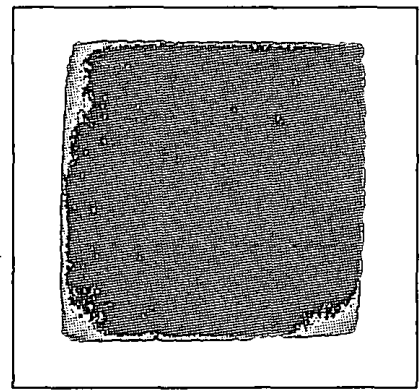

図25 D $100 \mathrm{~W} 1$ (東面) 10 時 00 分

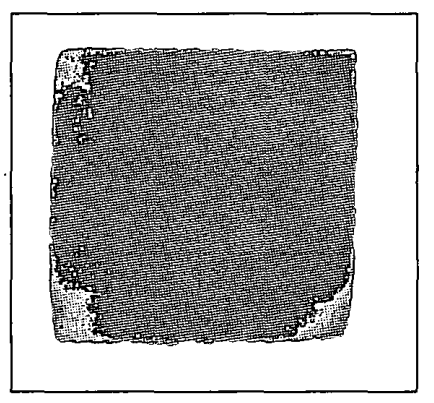

図 28 D $100 \mathrm{O} 1$ (西面) 15 時 30 分

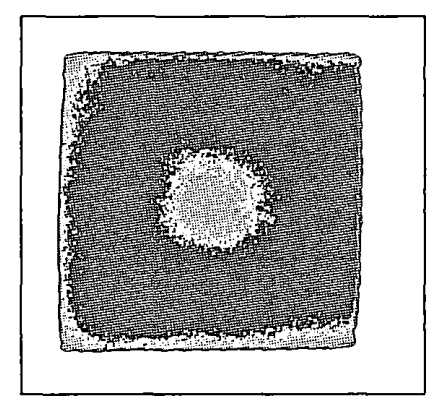

図 29 D $30 \mathrm{~W} 1$ (北面) 12 時 00 分

周囲にはベランダや空枠など熱の回り込みの原因となる ものが存在するので，実構造物における測定時にもこれ らの周囲に存在する剥離の検知は困難になることが予想 される。 
(2)サーモグラフィー法の適用に必要な日射量および気温 変化量は相当外気温度の概念を用いることによって一っ の外力エネルギー量にまとめることができる。これは， サーモグラフィー法の適用法の標準化を行う上で, 相当 外気温度変化量を定量的指標として用いることが可能で あることを示している。

(3)サーモグラフィー法の適用が困難であるとされてきた 北面でも，モルタル厚さが $30 \mathrm{~mm}$ 以下であれば，剥離検 知は可能である。

(4)赤外線映像装置の最小検知温度差は, 必ずしも肉眼で の剥㒕の認識が可能な限界と一致するとは限らない。つ まり，赤外線映像装置が剥離部に生じた極めて微小な表 面温度差を検知したとしても, 肉眼でそれを剥離と認識 するためには, 表面温度差の分布が剥離の形状と一致し た鮮明な形状で現れる必要がある。

(5)肉眼で剥離の存在を認識するためには, 健全部と剥離 部との間に赤外線映像装置で検知可能な表面温度差が生 じると同時に, 剥離部の輪郭が鮮明に現れる必要がある。 熱画像における剥離部の輪郭の鮮明さとは, 剥離部と健 全部との境界部における表面温度勾配の大きさを意味し， モルタル厚さが薄い場合は剥離部と健全部との境界部に 大きな表面温度勾配が生じるが，モルタル厚さが厚くな るほど，表面温度勾配がなだらかになるため，剥離の検 知は困難になる。

\section{6.あとがき}

本報では，サーモグラフィー法の標準化を目的する研 究の一環として，理想的な環境下における本手法の適用 限界について確認した。今後は解析的研究も交え，あら ゆる環境下におけるサーモグラフィー法の適用性につい て明らかにしていく予定である。
[謝辞]

本実験は，住友大阪セメント(株)中央研究所で実施し た。本実験に際してご協力を得た車田則充研究所長，小 林哲夫副主任研究員をはじめ, 同研究所の皆様ならびに 名古屋大学大学院生・叶錦氏に謝意を表する。なお，本 研究費の一部は, 平成 $5 \sim 6$ 年度文部省科学研究費補助 金・試験研究（B）によったことを付記する。

\section{引用文献}

1)谷川, 森, 安 : サーモグラフィーによる R C 構造物の内部欠宿探 查，コンクリート工学年次論文報告集，Vol $10-2$,

pp. $349-354,1988$

2)内山：熱画像を用いた境境計測法の建築外部空間への応用に関す る研究, 東京工業大学博士論文, pp.129-145，1994 3)新井：タイル仕上げ等の剥離保知器の開発，建設省技術評価書， pp. $36-42,1983$

4)T. Watanabe, Y. Kurakawa, HMori, and Y. Tanigawa Analytical Study on Estimation of Intemal Defect in Concrete Wall by Thermography, Trans. of Japan Concrete Institute, Vol. 15, pp. $281-287$, 1993

5)热，谷川，野田，込山：赤外線サーモグラフィー法による外壁仕 上げ材のはく離検知の適用限界に関する実験的研究，日本建築学 会東海支部研究報告集，№ 33 ,pp. 5 3-56，1995 6)込山，谷川，葉，中野: 赤外線サ一モグラフィー法による外壁仕 上げ材のはく離検知の適用限界に関する実験的研究，日本建築学 会大会学術講演梗概集, A, pp.1341-1342，1995 7)日本建築学会 : 建築設計资料集成 1 環境, 丸善, p 105 , 1978

8)畜藤：建築気候, 共立出版, pp.19-20, 1993

（1995年 9 月 10 日原稿受理，1996年 1月17日探用決定） 